\title{
Added sugars: Definitions, classifications, metabolism and health implications
}

\author{
Açúcares de adição: definições, classificações, \\ metabolismo e implicações à saúde
}

\author{
Tailane SCAPIN ${ }^{1}$ \\ Ana Carolina FERNANDES ${ }^{1}$ \\ Rossana Pacheco da Costa PROENÇA ${ }^{1}$
}

\section{A B S T R A C T}

The sugars added to foods have been featured in recent scientific research, including the publication of the World Health Organization recommendation to limit consumption of added sugars, based on studies on weight gain and dental caries. However, it is possible that there is evidence of an association between excessive consumption and other pathologies, but scientific studies have yet to investigate these associations. Moreover, there is no consensus on the descriptions and definitions of these sugars, with several terms and components used to designate them. In Brazil, there are few studies investigating added sugars, identifying a lack of discussion on this subject. This paper presents a literature review of sugars added to foods, from their definitions and classifications to the metabolism and health effects. The search was performed without limiting dates in the following databases: Web of Science, Scopus, PubMed and SciELO, as well as in national and international official sites. Keywords in Portuguese and English related to sugars added to foods were used, in combination with terms related to systematic review and meta-analysis studies, in order to find research linking added sugars consumption with health damage. The literature indicates that there is a relationship between excessive consumption of added sugars and various health outcomes, including weight gain, type 2 diabetes Mellitus, cancer, and cardiovascular diseases. The different descriptions of sugars in foods may confuse both food consumers and researchers, since each term includes different components. Thus, it is suggested to use the standardized term "added sugar" as the most suitable term for the broader population to understand, because it indicates that those sugars are not natural food components.

Keywords: Chronic disease. Food consumption. Food label. Sugar.

\footnotetext{
1 Universidade Federal de Santa Catarina, Centro de Ciências da Saúde, Departamento de Nutrição. Campus Univer-sitário, Trindade, 88040-9000, Florianópolis, SC, Brasil. Correspondência para/Correspondence to: RPC PROENÇA. E-mail: <rossana.costa@ufsc.br>.

Article based on the master's thesis of T SCAPIN, entitled: "Notificação dos açúcares de adição em rótulos de alimentos industrializados comercializados no Brasil”. Universidade Federal de Santa Catarina; 2016.

Support: Conselho Nacional de Desenvolvimento Científico e Tecnológico, Agência Nacional de Vigilância Sanitária (under Notice $n^{\circ} 5$ CNPq/ANVISA/2014) and by the Coordenação de Aperfeiçoamento de Pessoal de Nivel Superior.
} 


\section{RE S U M O}

Os açúcares adicionados aos alimentos estão em destaque em pesquisas científicas recentes, inclusive em decorrência da publicação da Organização Mundial da Saúde com recomendações de limitação do seu consumo, baseando-se em estudos sobre ganho de peso e cárie dental. Entretanto, é possivel que haja evidências de associação do consumo excessivo com outras patologias, mas não foram encontrados estudos que as reúnam. Além disso, ainda não há consenso científico quanto às denominações e definições desses açúcares. No Brasil, há poucos estudos que investigaram os açúcares de adição, identificando-se escassez de discussão a respeito. Diante disso, este artigo apresenta uma revisão de literatura sobre os açúcares adicionados aos alimentos, desde suas definições e classificações até o metabolismo e efeitos à saúde. A busca de informações foi realizada nos bancos de dados: Web of Science, Scopus, PubMed e SciELO, bem como em sites de órgãos oficiais nacionais e internacionais. Foram utilizados unitermos em português e inglês relacionados aos açúcares de adição e a estudos de revisão sistemática e metanálise, para identificação de pesquisas que associam seu consumo a prejuizos à saúde. A literatura aponta relação do consumo excessivo desses açúcares a diversos desfechos em saúde, incluindo ganho de peso, diabetes mellitus tipo 2, câncer e doenças cardiovasculares. As diferentes denominações dos açúcares nos alimentos podem confundir tanto os consumidores quanto os pesquisadores, uma vez que cada termo traz a inserção de componentes distintos. Assim, sugere-se padronização no uso do termo açúcares de adição, que parece ser o mais adequado para o entendimento da população, uma vez que indica que aquele açúcar não é natural do alimento.

Palavras-chave: Doença crônica. Consumo de alimentos. Rotulagem de alimentos. Açúcar.

\section{INTRODUCTION}

Carbohydrates are a type of macronutrient, consisting of carbon, hydrogen and oxygen. The smallest carbohydrate structures are monosaccharides, which can undergo different types of polymerization, forming complex sugars, starches, and fibers. Polyols may also be considered carbohydrates, albeit they include an alcohol group in their molecule [1].

Healthy sources of carbohydrates include whole grains, vegetables, fruits, and dairy products [1], which also contain a variety of health-beneficial bioactive compounds [2]. Another considerable source of carbohydrates are sugars, which have low quantities of vitamins, minerals, and fiber [3] when not naturally present in whole grains, vegetables, and dairy products. Therefore, limiting consumption of sugars is recommended [4].

Sugars added during food processing, culinary preparation, or during meals may be termed added sugars [5], free sugars [4], or non-milk extrinsic sugars [1]. The components of these sugars differ, depending on the nomenclature used, which is considered an obstacle to addressing the issue both in scientific studies and food legislation [6].

Added sugars have been highlighted in recent scientific publications, in part because of two major actions. The first was the proposal to change the food labeling laws, for the mandatory inclusion of added sugars on the nutrition facts panel, announced by the United States of America in 2014. This proposal was approved in May, 2016 [7]. Concurrently, Canada approved the inclusion of data for added sugars on food labels in January, 2017, after publishing a public consultation [8]. It should be noted that no other laws addressing added sugars have been identified worldwide.

The second event, with global impact, was the publication of a guidelines on free sugars intake by the World Health Organization (WHO), in 2015. The guidelines recommend limiting consumption of these sugars to less than $10 \%$ of the daily energy intake [4]. The report was based on two systematic reviews and meta-analysis studies, relating free sugars intake to weight gain [9] and dental caries [10]. However, evidence of the association between sugar excessive consumption and other Non- 
Communicable Diseases (NCDs) may already be available, because the consumption of added sugars exceeds the limit recommended by the WHO [4] in several countries [11,12], and the number of publications on the subject has been increasing in recent years.

Thus, this study aims to report a review of the literature on concepts and classification of sugars added to foods in an effort towards defining terms and gathering evidence associating the excessive consumption of those sugars with implications for human health.

\section{METHODS}

Data collection was performed by literature searches of articles published in the Web of Science, Scopus, PubMed, and SciELO databases, and in other sites of Brazilian and international official bodies, with no date restrictions. The search for papers occurred from July 2014 to October 2016. The following keywords were used in Portuguese and English: "açúcares de adição", "added sugars"; "açúcares livres", "free sugars"; "açúcares extrínsecos", "extrinsic sugars"; and/or "açúcares extrínsecos não lácteos", "non-milk extrinsic sugars".

The same aforementioned keywords were used in combination with the keywords "revisões sistemáticas", "systematic review" and "metanálise", "meta-analysis", "meta-analyses" to search for studies associating added sugars consumption with implications for human health.

Publications on sugar classification, term definition, metabolism, and effects of sugar consumption on health were analyzed. The research was not intended to guarantee the representativeness of the findings for quantitative analysis, but instead focused on how appropriate the data were to the study subject. Thus, papers with repeated data from similar sources were excluded, prioritizing inclusion of the original sources. Other bibliographic materials, including books and websites, were also searched.

\section{Classification and nomenclature of carbohydrates and sugars}

From the physiological standpoint, carbohydrates may be classified according to the effects of their metabolism, including: the intestinal absorption rate (fast and slow absorption), the effect on glycemic increase (low, medium and high glycemic index), or the colonic fermentation rate (digestible and non-digestible by intestinal bacteria) $[13,14]$. The glycemic index should be differentiated from the glycemic load herein. According to the WHO, the glycemic index is a food classification method regarding the area under the curve of the blood glucose response to the consumption of a test food containing $50 \mathrm{~g}$ of carbohydrates, in relation to the percentage response to the same quantity of carbohydrates of a standard food (white bread or glucose), and this value is expressed as percentage [1]. However, this method only considers carbohydrate quality. Subsequently, the glycemic load was calculated considering the type and quantity of food carbohydrate. The glycemic index value of the food is multiplied by the quantity of carbohydrate in an average portion of that food and then divided by one hundred, to calculate the glycemic load. Thus, glycemic load is a more reliable method to assess the glycemic response to the consumption of a specific food, because it considers the quantity of food usually consumed [15].

Carbohydrates may be classified according to chemical-structural properties, considering their degree of polymerization, in addition to their classification by physiological effects. The degree of polymerization pertains to the number of monomers in a molecule, in this case, the number of monosaccharides. This classification categorizes carbohydrates into four groups: sugars, oligosaccharides, polysaccharides, and polyols $[1,16]$. 
The first group of sugars includes monosaccharides, which are the smallest carbohydrate structures and have only one saccharide unit, and disaccharides, which have two monosaccharide units. The second group of carbohydrates is the oligosaccharides, which have from three to nine saccharide units in their molecular structure and include maltooligosaccharides and other oligosaccharides. The third group consists of polysaccharides, which have more than nine monosaccharide units in the molecular structure and include both starches and non-starch polysaccharides (e.g., cellulose and chitin). Lastly, the fourth group includes the polyols, which are hydrogenated carbohydrates, formed by carbohydrate and alcohol groups, which may be mono-, di-, oligo-, or polysaccharides. Polyols may have different degrees of polymerization, depending on the carbohydrate group $[1,16]$. Table 1 outlines the main carbohydrates present in the human diet, according to the classification based on the degree of polymerization, subgroups, and components.

Some authors argue that classifying carbohydrates into various chemical groups complicates the correlation with their physiological effects. According to the WHO [1] and Cumming \& Stephen [13], the classification strictly based on chemistry precludes the respective translation into nutritional terms because each of the main carbohydrate classes has various physiological effects and, therefore, various implications for human health.

For example, in the WHO report [1], polyols, also known as sugar alcohols, that are formed from molecules of mono- and disaccharides, such as mannitol and sorbitol, are considered to belong to the sugars group, because they have the same degree of polymerization as their respective constituents. However, the classification of polyols as sugars is erroneous, according to Livesey [16], because they also have the alcohol group in their molecular structure, and, therefore, differ in terms of both the chemical-structural and the physiological effects.

Thus, the literature indicates that the term "sugars", (in plural), is consensually used to refer to mono and disaccharides $[1,13,17,18]$, and the term "total sugars" has the same meaning [4]. Thus, the term "sugars" excludes polyols.

However, the term sugar, used in the singular form, usually refers only to purified sucrose or refined sugar $[1,19]$. Confirming this meaning, the Agência Nacional de Vigilância Sanitária defines sugar as "sucrose obtained from Saccharum officinarum or Beta alba, $L$. through a suitable technological process" [20]. However, it is emphasized that some palms are used as sources of sucrose, in addition to sugarcane and beet. Sucrose is the main product

Table 1. Chemical/structural classification of the main dietary carbohydrates, according to the degree of polymerization.

\begin{tabular}{|c|c|c|c|}
\hline Classification & DP & Subgroup & Components \\
\hline \multirow{2}{*}{ Sugars } & 1 & Monosaccharides & Glucose, galactose, fructose \\
\hline & 2 & Disaccharides & Sucrose, lactose, maltose, trehalose \\
\hline \multirow{2}{*}{ Oligosaccharides } & \multirow{2}{*}{$3-9$} & Malto-oligosaccharides & Maltodextrin \\
\hline & & Other oligosaccharides & Raffinose, stachyose, fructooligosaccharide \\
\hline \multirow{2}{*}{ Polysaccharides } & \multirow{2}{*}{$>9$} & Starch & Amylose, amylopectin, modified starches \\
\hline & & Non-starch polysaccharides & Cellulose, hemicellulose, pectins, hydrocolloids \\
\hline Polyols & $1->9$ & - & $\begin{array}{l}\text { Erythritol, xylitol, mannitol, sorbitol, maltitol, isomalt, lactitol, } \\
\text { polyglycol. }\end{array}$ \\
\hline
\end{tabular}

Note: DP: Degree of Polymerization.

Source: Modified from World Health Organization [1] and Livesey [16]. 
of photosynthesis in plants, and naturally occurs in the fruits, vegetables, nectar, and sap of various plants [21]. The use of the term sugar as a synonym of sucrose is also cited internationally, including by the $\mathrm{WHO}$, therefore justifying its use in this article $[1,19]$.

In addition to the physiological and chemical-structural classifications, sugars may also be classified based on their occurrence in nature. Sugars added to processed foods, during food preparation, or during meals, which are not naturally present in foods in their intact form, may be termed added sugars [5,22], free sugars [4], or non-milk extrinsic sugars [1]. These definitions are discussed below.

\section{Definitions of added sugars and similar terms}

According to the World Health Organization [1] and Cummings \& Stephen [13], one of the first proposals for the classification of sugars, based on their natural forms, was published in the United Kingdom in 1989 and categorized sugars into intrinsic and extrinsic sugars.

Intrinsic sugars were defined as plant sugars, that is, sugars naturally occurring in plant foods and other fruit nutrients, such as fructose and sucrose. Conversely, extrinsic sugars were defined as sugars that are not found in the cellular structure of plants, which may be added during food preparation or processing. Furthermore, lactose was considered an extrinsic sugar, according to this classification, because it is not a structural component of plants. However, lactose is metabolized similarly to the intrinsic sugars. Thus, the scientific literature only indicates health damage due to its consumption for individuals with lactose-related diseases, including lactose intolerance [23]. Therefore, the term non-milk extrinsic sugars was established to differentiate extrinsic sugars from lactose $[1,13]$.

However, the criteria established to determine such classifications may apparently cause confusion because lactose is considered extrinsic, despite the specific term non-milk extrinsic sugars differentiating lactose from the other extrinsic sugars. Thus, the fact that lactose is not included in the structure of plants does not necessarily render it an extrinsic sugar because lactose is naturally found in the composition of milk and its derivatives, and is not added to these foods. Thus, such a classification presumably aimed to differentiate health-harming sugars from harmless sugars [1]. Therefore, lactose could not be considered an extrinsic sugar. It should be noted that individuals with pathologies related to carbohydrate metabolism or consumption, like galactosemia, fructosemia, and intolerances or allergies to milk sugars, are excluded when considering these classifications.

The new United Kingdom guidelines for carbohydrates and health recommend replacing the term "non-milk extrinsic sugars" with the term "free sugars" to avoid misunderstanding about the categorization of sugars, most likely because of possible doubts that may arise when using these terms (intrinsic sugars, extrinsic sugars and non-milk extrinsic sugars) [24].

Another term used to differentiate sugars based on their occurrence in nature is "added sugars". The term added sugars was defined in 2000 by the United States Department of Agriculture (USDA) to help consumers identify processed foods and beverages containing added sugars [22]. This definition, reiterated by the USDA in 2015 [5] and used by the Food and Drug Administration (FDA) [7], states that added sugars are sugars and syrups added to foods and beverages during food processing, preparation, and meals, including fruit juice concentrate and honey and excluding sugars naturally occurring in foods, such as fructose in fruit and lactose in milk.

It is noteworthy that, according to the FDA definition, a sugar naturally occurring in a specific food (including fructose and sucrose in fruit) extracted and isolated from the source food and added to another food will no longer 
be considered naturally present in the new food and is classified as an added sugar [7].

Similar to the definition of added sugars, the term "free sugars" was originally defined by the WHO in 2003 [18] and updated by the same organization in 2015 [4]. The WHO definition states that free sugars are mono- and disaccharides added to foods and beverages by the manufacturer, cook, or consumer, and sugars naturally present in honey, syrups, fruit juices, and fruit juice concentrate [4].

From a definition standpoint, the term added sugars differs from free sugars in that the latter includes natural fruit juices. Thus, added sugars only include fruit juice concentrates, whereas free sugars include fruit juice concentrates and fresh juices. Both exclude lactose, which is included in the definition of extrinsic sugars $[1,13]$. Figure 1 shows a scheme differentiating sugar components, depending on the type of term used.

This variety of terms used becomes a challenge for the scientific community, according to Erickson \& Slavin [25]. Furthermore, authors

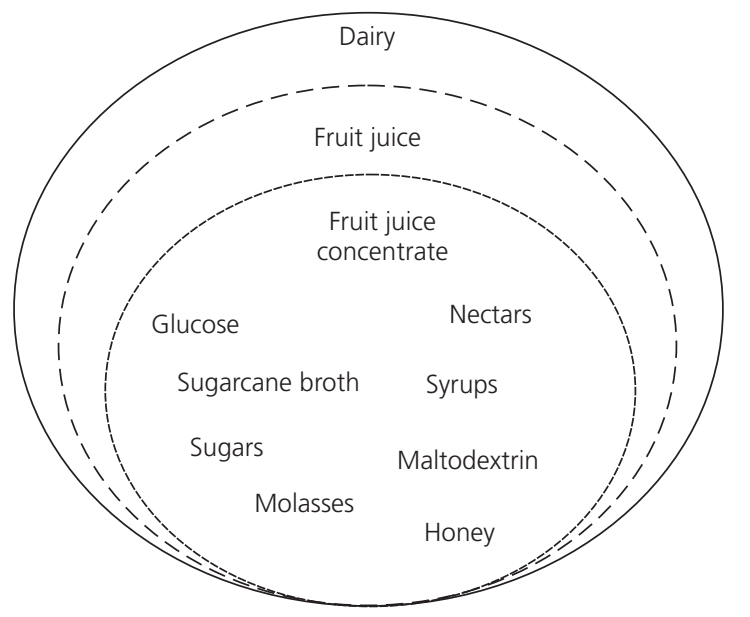

Extrinsic sugars ${ }^{a}$ _-__-_Free sugars ${ }^{b}$....... Added sugars $c$

Figure 1. Differences in sugar components according to the term used: extrinsic, free, or added sugars.

Note: ${ }^{a}$ World Health Organization [1] and Cummings \& Stephen [13]; ' b'World Health Organization [4]; 'United States Department of Agriculture [5,20] and Food and Drug Administration [7]. indicate that the adoption of sugar consumption recommendations may be impaired if the terms, including total sugars, added sugars, and free sugars, are not well defined. The scientific literature and official reports lack the acceptance and universal use of a single term to refer to sugars added to foods, according to Van Horn et al. [19].

The term added sugars is used in scientific articles as well as current food and nutrition guidelines in various countries, including Australia [26], New Zealand [27], South Africa [28], and the United States [5]. Furthermore, organizations based in the United States, including the American Heart Association [19], the American Diabetes Association [29], and the Institute of Medicine [3]; and European bodies, including the European Food Safety Authority [30], also use the term added sugars. As already mentioned, the laws that refer to added sugars are the food labeling legislation approved by the United States [7] and Canada [8]. Conversely, the term free sugars has been adopted by the WHO [4], though this term is used less frequently in scientific papers on the subject, and no legislation includes this term.

In Brazil, the most recent version of the Food Guide for the Brazilian Population [31] fails to use a specific term referring to sugars added to processed foods and food preparations or during meals. "Sugar", which is consensually defined as being synonymous with sucrose by the scientific literature and laws, is the only term found. The previous version of the Food Guide for the Brazilian Population used the term sugars, defined as mono- and disaccharides, however it did not separate natural and added sugars [32].

Another difficulty in defining the term "added sugars" is the lack of systematic data on the identification of components of those sugars. The literature indicates this includes certain compounds, including corn syrup, refined sugar, and honey $[4,33,34]$. However, 
only one comprehensive survey about that was found in Portuguese [34].

Thus, considering the questions discussed above, including the lack of consensus on the classification and definition of sugars, and the current use of the term "added sugars", in both Brazilian and international scientific literature, the use of the term "added sugars" is suggested. However, we suggested the following definition: "Added sugars are sugars and syrups added to foods and beverages during food processing, preparation, or meals. They include compounds such as white sugar, high-fructose corn syrup, honey, and fruit juice and fruit juice concentrates, among others, and exclude sugars naturally present in foods, such as lactose in milk and sucrose and/or fructose in fruit. A sugar naturally occurring in a specific food, including fructose and sucrose, extracted and isolated from its source food and added to another food will be classified as an added sugar in the new food". In this context, and due to the similar metabolism effects of free sugars discussed below, we suggest including fresh fruit juices to the concept of added sugars, different to the original definition by USDA $[5,20]$ and FDA [7].

\section{Sugar metabolism and health effects}

Although carbohydrate digestion begins in the mouth, most carbohydrates remain relatively undigested until reaching the small intestine, where pancreatic secretions containing amylases are released to break carbohydrates into smaller polymers, regardless of the food source [23].

At the surface of the small intestine, microvilli enzymes (maltase, sucrose, trehalase, and lactase) break the respective disaccharides (maltose, sucrose, trehalose, and lactose) into monosaccharides, the form in which they will be absorbed. Glucose and galactose absorption by enterocytes is performed by active transport, that is, Adenosine Triphosphate (ATP)-dependent transport, through a sodium-potassium ion exchange pump. Conversely, fructose is preferentially absorbed by facilitated diffusion, but may also be absorbed by glucose-dependent transport; both pathways are saturable. The fructose absorption capacity is approximately half of the quantity of glucose or galactose absorbed, due to pathway saturation [23].

After absorption, monosaccharides are directed to the portal circulation and transported to the liver where they undergo phosphorylation. Hepatocytes convert almost all fructose and galactose into glucose, which, together with the glucose present, are released into the bloodstream [35]. Glucose is the preferential source of energy for brain cells (except during prolonged fasting, wherein ketone bodies may be used) and for red blood cells, without requiring transporters.

All monosaccharides may be metabolized for energy production. Each gram generates approximately $4 \mathrm{kcal}$ and produces approximately 38 moles of ATP/mole of metabolized glucose [23]. The main sugar-derived metabolic pathway of energy production is glycolysis. Although glucose, fructose, and galactose enter the glycolytic pathway at different points, each ultimately produces two molecules of pyruvate, which are then converted into acetyl-Coenzyme A. In turn, acetyl-Coenzyme A is completely oxidized through the Krebs cycle and the electron transport chain to produce ATP, carbon dioxide, and water under aerobic conditions, or converted into lactate under anaerobic conditions [23,35].

After the metabolism of monosaccharides, the glycemic increase stimulates the release of insulin from the pancreas, thereby leading to glucose uptake and utilization by all body tissues, and converted for storage, as glycogen, in the liver and muscles. Glycogen storage is limited by its quantity of water, and the excess is directed to lipogenesis [23].

Fructose metabolism is slightly different from the metabolism of the other sugars. 
Although fructose is primarily metabolized in the liver, the enzymes needed for fructose metabolism are also found in the intestine and kidneys. Fructose also differs because no energy is spent and no insulin stimulus is required for uptake and phosphorylation in the liver. Furthermore, phosphorylated fructose may form two trioses, which in turn may follow three different paths: to participate in the glycolytic pathways providing pyruvate and releasing energy (such as in the metabolism of other sugars); to be reduced into glycerol, which is required to synthesize triacylglycerols, phospholipids, and other lipids; or to be condensed into forming fructose-1,6diphosphate and, subsequently, glucose or glycogen [36].

The glucose formed is used immediately or is converted into triglycerides stored in adipocytes by lipogenesis, as previously reported [23]. The lipogenesis of excess glucose is one of the mechanisms responsible for the association of excessive intake of added sugars with weight gain/obesity [37]. The intake of more than $50 \mathrm{~g}$ added sugars per day (>10\% total energy value) is related to an average increase of $0.75 \mathrm{~kg}$ of body fat in adults, according to a systematic review [9]. Malik et al. [38] showed in their review that the increase in the consumption of one portion per day ( 26g) of added sugars from sugary beverages was associated with an increase in body weight in adults.

In addition to increased body weight, the glucose shunted to lipogenesis, particularly glucose derived from fructose metabolism, results in the hepatic formation of excess triglycerides, which are transported by very low-density lipoproteins to the adipose tissue for storage [37], thereby causing hypertriglyceridemia. This may also lead to elevated Low-Density Lipoprotein (LDL) levels, possibly stimulating visceral, hepatic, and muscular adiposity. This pathway may cause peripheral insulin resistance through physiological mechanisms involving oxidative stress [39].
Insulin-resistant tissues induce increased insulin secretion from the pancreas, which tries to compensate for the unused glucose and may lead to pancreatic beta cell dysfunction [23]. Over time, this deterioration possibly leads to inadequate insulin secretion and progresses to diabetes [40]. The intake increase of one can $(330 \mathrm{~mL})$ of sugar-sweetened soft drinks per day is associated with a $20 \%$ increase in the risk of developing type 2 diabetes Mellitus, according to a systematic review [41]. Another meta-analysis showed that individuals with higher fruit juice intake had a 1.14-times higher relative risk of developing diabetes [42].

Pancreatic cell dysfunction may also lead to increased cellular proliferation, which tends to progress to pancreatic cancer. In a systematic review, Aune et al. [43] showed a 22\% higher risk of developing pancreatic cancer with each increase of $25 \mathrm{~g}$ of fructose per day, derived from sugary beverages. Evidence indicating the relationship between the consumption of added sugars and colorectal cancer has also been published [44-46].

Furthermore, the increase in plasma triglycerides and LDL cholesterol, and the decrease in High-Density Lipoprotein (HDL), is typical of dyslipidemia [47] and may be caused by excessive consumption of added sugars [48]. Individuals with higher intakes of added sugars had higher serum triglyceride, total cholesterol, and LDL levels than those with lower intake, according to a systematic review [49].

Dyslipidemia is among the risk factors for cardiovascular diseases, and evidence indicating positive associations between the intake of added sugars and the risk of developing such diseases has been published [9,50-52]. The mechanisms involved in the association between cardiovascular diseases and the intake of added sugars are also apparently related to the increase in dietary glycemic load, with an increase in blood glucose levels and insulin demand in the body [50]. 
Uric acid production that occurs during fructose metabolism [36] as a secondary metabolite, which exponentially increases with the intake of fructose derived from sugary beverages [53], should also be considered. Hyperuricemia caused by fructose metabolism may be related to an increased risk of developing gout, according to a cohort study of men in the United States [53]. Furthermore, increased uric acid production is one of the main hypothesis for the relationship between the intake of added sugars and arterial hypertension [54].

Fructose apparently plays different roles towards increasing blood pressure, according to a review study [55]. First, fructose increases uric acid production in the body. Second, fructose may be absorbed differently from the other monosaccharides, which may cause increased sodium and water influx in the jejunum, causing high blood pressure. Third, fructose promotes the vasoconstriction of renal tubules. Evidence on the last mechanism indicates a relationship between added fructose intake and renal diseases, in addition to high blood pressure. However, the findings with positive associations result from animal research [56], and may not translate to humans.

Isocaloric fructose replacement by other carbohydrates in the adult diet decreases the diastolic and mean blood pressure, according to a meta-analysis of the effects of fructose on blood pressure [57]. In another systematic review, ten of the twelve studies evaluated showed a positive relationship between an increased intake of sugary beverages, primarily consisting of fructose, and an increase in blood pressure [58]. Therefore, we also considered fruit juice (not only the concentrate) in our definition of "added sugar".

Considering the space limitations in the article and the lack of scientific discussion of the other study topics, we focused on the classification and definition of sugars rather than on metabolism, which is examined in more detail in basic biomedical books $[23,35]$.
Some systematic review and metaanalysis studies found in the search performed focused on the relationship between the consumption of added and/or free sugars and the implications for human health, resulting from the metabolism of sugars in the human body, as outlined in Chat 1.

Most review studies outlined in Chat 1 were performed in the American population, due to the lack of published evidence from other locations. Furthermore, most studies evaluated the intake of added sugars derived from sugary beverages (mostly sodas), especially added fructose, the main component of these beverages in the United States [21]. The publications on these topics are also relatively recent, showing an increase in scientific interest in the subject.

The literature indicates that low-calorie sweeteners are used as sugar substitutes to reduce or remove added sugars from a food, thereby decreasing their consumption or the caloric intake $[1,59]$.

Replacing added sugars by low-calorie sweeteners may lead to a short-term decrease in caloric intake, according to the most recent version of the Dietary Guidelines for Americans [5]. However, doubts about the effectiveness of this technique as a strategy for long-term body weight management remain.

Sweeteners may be divided into two groups, according to the WHO: nonnutritive and nutritive sweeteners. Nonnutritive sweeteners have an intensely sweet flavor and provide no or very low quantities of calories. Conversely, nutritive sweeteners, such as added sugars, provide calories [1].

More recently, the American Dietetic Association also adopted such a classification, albeit defining sweeteners as those containing carbohydrates. The American Dietetic Association classifies carbohydrates into mono- and disaccharides, whose energy value is up to $4 \mathrm{kcal} / \mathrm{g}$ (also referred to as caloric sweeteners or added sugars), and into polyols, which provide 
Chart 1. Systematic reviews and meta-analyses relating the consumption of added and/or free sugars to health implications.

\begin{tabular}{llll}
\hline Author (year) & Characteristics & Exposure and outcome & Results/Conclusions \\
\hline \multicolumn{4}{c}{ CARDIOVASCULAR DISEASES } \\
\hline Huang et al. & $\begin{array}{l}\text { Systematic review and meta- Consumption of sugar- } \\
\text { (2014) [50] }\end{array}$ & $\begin{array}{l}\text { analysis of } 4 \text { prospective studies } \\
\text { (over } 9 \text { years of follow-up) in } \\
\text { adults. }\end{array}$ & for coronary heart disease.
\end{tabular}

Te Morenga et al. (2014) [49]

Wang et al. (2014) [51]

Zhang et al. (2013) [52]
Systematic review and metaanalysis of 39 clinical trials in adults and children.

Systematic review and metaanalysis of 11 clinical trials in adults with and without health changes.
Consumption of free sugars and cardiovascular diseases.

Significant positive association between high free sugars intake and increased triglyceride, total cholesterol and HDL concentration, systolic blood pressure and markers for the risk of developing cardiovascular diseases.

Fructose consumption and Increased triglycerides in overweight/ postprandial triglycerides.

postprandia triglycerides.
obese subjects and tendency towards increased postprandial triglycerides in healthy subjects upon isocaloric replacement of other simple carbohydrates by fructose. Increase in postprandial triglycerides upon supplementation with fructose in all groups.

Systematic review and meta- Fructose (sugar- sweetened Positive dose-response relationship of analysis of 22 clinical trials in beverages) consumption adults and children. effects on total and fraction cholesterol.

fructose consumption greater than $100 \mathrm{~g} /$ day with total cholesterol and fructose consumption, even lower than $100 \mathrm{~g} /$ day, and increase in LDL. No significant association between fructose and $\mathrm{HDL}$.

DENTAL CARIES

$\begin{array}{ll}\text { Moynihan \& Kelly } & \text { Systematic review of } 55 \text { Total, added, free and non-milk } \\ \text { (2014) [10] } & \text { randomized clinical trials and extrinsic sugar consumption } \\ & \text { intervention and observational and dental caries. } \\ & \text { studies in adults and children. }\end{array}$

TYPE 2 DIABETES MELLITUS

\begin{tabular}{|c|c|c|c|}
\hline \multicolumn{4}{|c|}{ TYPE 2 DIABETES MELLITUS } \\
\hline $\begin{array}{l}\text { Greenwood et al. } \\
(2014)[41]\end{array}$ & $\begin{array}{l}\text { Systematic review and meta- } \\
\text { analysis of } 9 \text { prospective studies } \\
\text { (with more than six years of } \\
\text { follow-up) in adults. }\end{array}$ & $\begin{array}{l}\text { Consumption of sugar- } \\
\text { sweetened and artificially } \\
\text { sweetened soft drinks and } \\
\text { DM2. }\end{array}$ & $\begin{array}{l}\text { Significant positive association between } \\
\text { sugar-sweetened beverage consumption } \\
\text { and DM2, maintaining statistical } \\
\text { significance after adjustment for body } \\
\text { mass index. The association was higher } \\
\text { for drinks with sugar than with artificial } \\
\text { sweeteners, with a } 20 \% \text { increase in the } \\
\text { risk for DM2. }\end{array}$ \\
\hline $\begin{array}{l}\text { Xi et al. } \\
\text { (2014) [42] }\end{array}$ & $\begin{array}{l}\text { Systematic review and meta- } \\
\text { analysis of } 10 \text { prospective } \\
\text { studies (with more than } 5 \text { years } \\
\text { of follow-up) in adults. }\end{array}$ & $\begin{array}{l}\text { Consumption of fruit juice, } \\
100 \% \text { natural or sweetened, } \\
\text { and DM2 incidence. }\end{array}$ & $\begin{array}{l}\text { Significant positive association between } \\
\text { fruit juice consumption (regardless } \\
\text { of type) and the risk of developing } \\
\text { DM2. Risk stratification showed a } \\
28 \% \text { increase for DM2 incidence with } \\
\text { sweetened fruit juice consumption, } \\
\text { whereas no significant association with } \\
100 \% \text { natural fruit juice consumption } \\
\text { was found. }\end{array}$ \\
\hline
\end{tabular}

Increased presence of caries proportional to sugar consumption ( $>10 \%$ total energy value) and decreased incidence of caries also proportional to sugar consumption ( $<10 \%$ total energy value). 
Chart 1. Systematic reviews and meta-analyses relating the consumption of added and/or free sugars to health implications.

\begin{tabular}{|c|c|c|c|}
\hline Author (year) & Characteristics & Exposure and outcome & Results/Conclusions \\
\hline \multicolumn{4}{|c|}{ BODY WEIGHT } \\
\hline
\end{tabular}

Malik et al. Systematic review of 30 cross- Consumption of sugar- Significant direct association between

(2006) [38] sectional, prospective cohort, sweetened beverages (soft drinks, increased consumption of sodas and other (with more than 6 months of soda, fruitades, fruit drinks, sports sugar- sweetened beverages and body follow-up) and experimental drinks, sweetened iced tea, weight gain. studies in adults and children. squashes, and lemonade) and weight gain and/or obesity.

Te Morenga, Systematic review and metaMallard \& Mann analysis of 68 prospective (2013) [9] studies (with more than two years of follow-up) and randomized, controlled trials in adults and children.
Consumption of total sugars and body weight.
Increased or decreased dietary sugar intake associated with corresponding body weight changes in adults and children. However, the effect of increased sugar consumption body weight gain is apparently stronger than the effect of decreased sugar on weight reduction.

\begin{tabular}{|c|c|c|c|}
\hline \multicolumn{4}{|c|}{ ARTERIAL HYPERTENSION } \\
\hline $\begin{array}{l}\text { Ha et al. } \\
(2012) \text { [57] }\end{array}$ & $\begin{array}{l}\text { Systematic review and meta- } \\
\text { analysis of } 11 \text { randomized } \\
\text { clinical trials in adults. }\end{array}$ & $\begin{array}{l}\text { Fructose consumption and } \\
\text { blood pressure. }\end{array}$ & $\begin{array}{l}\text { Decrease in mean arterial pressure and } \\
\text { diastolic pressure proportional to fructose } \\
\text { replacement by other dietary carbohydrates } \\
\text { (sucrose or glucose) without changing the } \\
\text { total caloric intake. }\end{array}$ \\
\hline $\begin{array}{l}\text { Malik et al. } \\
\text { (2014) [58] }\end{array}$ & $\begin{array}{l}\text { Systematic review and } \\
\text { meta-analysis of } 12 \text { studies } \\
\text { in adolescents and adults } \\
\text { without methodological } \\
\text { design restrictions. }\end{array}$ & $\begin{array}{l}\text { Sugar-sweetened } \\
\text { beveragesand blood pressure. }\end{array}$ & $\begin{array}{l}\text { Positive relationship between sugar- } \\
\text { sweetened beveragesconsumption and the } \\
\text { increase in blood pressure and the risk for } \\
\text { arterial hypertension incidence. }\end{array}$ \\
\hline \multicolumn{4}{|c|}{ CANCER } \\
\hline $\begin{array}{l}\text { Aune et al. } \\
(2012)[43]\end{array}$ & $\begin{array}{l}\text { Systematic review and meta- } \\
\text { analysis of } 13 \text { prospective or } \\
\text { cohort nested case-control } \\
\text { studies in adults. }\end{array}$ & $\begin{array}{l}\text { Consumption of simple } \\
\text { carbohydrates, glycemic index } \\
\text { and/ or glycemic load and risk } \\
\text { for pancreatic cancer. }\end{array}$ & $\begin{array}{l}\text { Positive association between fructose intake } \\
\text { and increased risk for pancreatic cancer, with } \\
\text { a } 1.22 \text { risk ratio for each } 25 \mathrm{~g} \text { fructose/day } \\
\text { dietary increase. }\end{array}$ \\
\hline $\begin{array}{l}\text { Galeone et al. } \\
(2012)[46]\end{array}$ & $\begin{array}{l}\text { Systematic review and meta- } \\
\text { analysis of } 36 \text { prospective and } \\
\text { case-control studies in adults. }\end{array}$ & $\begin{array}{l}\text { Consumption of added } \\
\text { sugars (mainly sugar-sweetened } \\
\text { beverages), glycemic index and } \\
\text { load and risk for colon cancer. }\end{array}$ & $\begin{array}{l}\text { Meta-analysis, primarily based on case- } \\
\text { control studies, found a } 1.25 \text { risk ratio } \\
\text { between high added sugars intake and the } \\
\text { risk for colorectal cancer, with inconsistent } \\
\text { results of glycemic index and load. }\end{array}$ \\
\hline
\end{tabular}

Note: HDL: High Density Lipoprotein; LDL: Low Density Lipoprotein; DM2: Diabetes Mellitus 2.

up to $2 \mathrm{kcal} / \mathrm{g}$. Nonnutritive sweeteners are defined as sweeteners that provide sweetness without energy or with negligible values, using the terms high-intensity sweeteners, low-calorie sweeteners and non-caloric sweeteners as synonyms, for example, acesulfame- potassium (ace-k), aspartame, cyclamate, stevia, neotame, saccharin, and sucralose [60].

However, such classifications are only based on caloric content, overlooking the physiological effects of low-calorie sweeteners on the body. A systematic review with metaanalysis [61] has reported evidence indicating a significant, positive association between substituting the use of sugars by low-calorie sweeteners and weight loss in adults. However, other studies have shown that frequent consumption of low-calorie sweeteners is associated with an increased risk of excessive weight gain [62-64], type 2 diabetes [41,63], metabolic syndrome, and cardiovascular diseases [63]. Moreover, foods containing low-calorie 
sweeteners maintain a sweet taste, which may affect the brain satiety system and generate a compensation system for the low-energy intake, leading to a subsequent increase in caloric intake [65]. Other articles disusing in detail the effects of low-calorie sweetener intake on the body are recommended because this is not the focus of the present review $[64,66,67]$.

Thus, although the issue is controversial, substituting added sugars by low-calorie sweeteners may result in caloric reduction, this approach does not prevent the diseases associated with excessive consumption of sugars, thereby demonstrating the need for scientific research on the subject.

\section{FINAL CONSIDERATIONS}

Different terms are used in the literature to refer to sugars added to foods, as assessed throughout this review.

Some strategies could be implemented to settle this problem, including adopting a standardized and universal term for sugars added to food for both technical and scientific use. Standardizing the use of the term added sugars is suggested because the purpose is to differentiate sugars according to their health effects and to identify sugars added to foods. Furthermore, this term may facilitate the understanding of the population because it indicates that those sugars are not natural components of the food, and that they were added during processing.

Including the term added sugars in food laws and requiring their identification in food labels could stimulate nomenclature standardization. In turn, food and nutrition agencies, including councils and associations of healthcare professionals, should publicize and define the term, which could also be a strategy to standardize its use. Moreover, key sources for this information, including official food and nutrition information materials, such as the
Food Guide for the Brazilian Population, can implement this term and increase population awareness.

The mandatory labeling of added sugars on the nutrition facts panel of processed foods is not currently required by Brazilian law. Such labeling could be helpful to consumers to reduce the consumption of added sugars, which is associated with harmful health outcomes, including obesity, type 2 diabetes Mellitus, cancer, and cardiovascular diseases.

\section{CONTRIBUTORS}

T SCAPIN contributed data collection, analyzed and interpreted the results, and prepared, wrote, and reviewed the manuscript. RPC PROENÇA and AC FERNANDES conceived and designed the study, analyzed and interpreted the results, and reviewed the manuscript. All authors approved of the final manuscript.

\section{REFERENCES}

1. World Health Organization. Carbohydrates in human nutrition. Geneva: WHO; 1998.

2. Slavin J. Whole grains and human health. Nutr Res Rev. 2004;17(1):99-110.

3. Institute of Medicine. Dietary Reference Intakes for energy, carbohydrate, fiber, fat, fatty acids, cholesterol, protein, and amino Acids. Washington (DC): National Academy of Sciences; 2002.

4. World Health Organization. Guideline: Sugars intake for adults and children. Geneva: WHO; 2015.

5. Office of Disease Prevention and Health Promotion. 2015-2020 Dietary Guidelines for Americans. Washington (DC): Office of Disease Prevention and Health Promotion; 2015.

6. Pomeranz JL. The bittersweet truth about sugar labeling regulations: They are achievable and overdue. Am J Public Health. 2012;102(7):14-20. https://doi.org/10.2105/AJPH.2012.300732

7. Food and Drug Administration. Food labeling: Revision of the nutrition and supplement facts labels. Washington (DC): Food and Drug Administration; 2016. 
8. Canada Gazette. Regulations amending the food and drug regulations (nutrition labelling, other labelling provisions and food colours). Canada Gazette. 2016 [cited 2016 Jan 12];150(25). Available from: http://www.gazette.gc.ca/rp-pr/ p2/2016/2016-12-14/html/sor-dors305-eng.php

9. Te Morenga L, Mallard S, Mann J. Dietary sugars and body weight: Systematic review and metaanalyses of randomised controlled trials and cohort studies. BMJ. 2012;346:e7492. https://doi. org/10.1136/bmj.e7492

10. Moynihan PJ, Kelly SA. Effect on caries of restricting sugars intake: Systematic review to inform WHO guidelines. J Dent Res. 2014;93(1):8-18. https://doi.org/10.1177/0022034513508954

11. Food and Agriculture Organization of the United Nations. Food and nutrition in numbers. Roma: Food and Agriculture Organization of the United Nations; 2014.

12. Newens KJ, Walton J. A review of sugar consumption from nationally representative dietary surveys across the world. J Hum Nutr Diet. 2016;29(2):225-40. https://doi.org/10.1111/jhn.12338

13. Cummings JH, Stephen AM. Carbohydrate terminology and classification. Eur J Clin Nutr. 2007;61(Suppl.1):S5-18. https://doi.org/10.1038/ sj.ejen. 1602936

14. Englyst HN, Hudson GJ. The classification and measurement of dietary carbohydrates. Food Chem. 1996;57(1):15-21. https://doi.org/10.10 16/0308-8146(96)00056-8

15. Salmerón J, Ascherio A, Rimm EB, Colditz GA, Spiegelman D, Jenkins DJ, et al. Dietary fiber, glycemic load, and risk of NIDDM in men. Diabetes Care. 1997;20(4):545.

16. Livesey G. Health potential of polyols as sugar replacers, with emphasis on low glycaemic properties. Nutr Res Rev. 2003;16(2):163-91. https://doi.org/10.1079/nrr200371

17. Sigman-Grant M, Morita J. Defining and interpreting intakes of sugars. Am J Clin Nutr. 2003;78(4):815s-26s

18. World Health Organization. Diet, nutrition and the prevention of chronic diseases. Geneva: WHO; 2003.

19. Van Horn L, Johnson RK, Flickinger BD, Vafiadis DK, Yin-Piazza S. Translation and implementation of added sugars consumption recommendations: A conference report from the American Heart Association Added Sugars Conference 2010. Circulation. 2010;122(23):2470-90. https://doi. org/10.1161/CIR.0b013e3181ffdcb0

20. Agência Nacional de Vigilância Sanitária. Resolução $n^{\circ} 12$ de 1978: aprova normas técnicas especiais, do Estado de São Paulo, revistas pela CNNPA, relativas a alimentos (e bebidas), para efeito em todo território brasileiro. Diário Oficial [da] União; 197824 jul.

21. Barclay A, Sandall P, Shwide-Slavin C. The ultimate guide to sugars and sweeteners. New York: The Experiment; 2014.

22. United States Department of Agriculture. Report of the Dietary Guidelines Advisory Committee on the Dietary Guidelines for Americans, 2000. Washington (DC): United States Department of Agriculture; 2000.

23. Guyton AC, Hall JE. Tratado de fisiologia médica. Guanabara Koogan; 2011.

24. The Stationery Office. Carbohydrates and health. London: The Stationery Office; 2015.

25. Erickson J, Slavin J. Total, added, and free sugars: Are restrictive guidelines science-based or achievable? Nutrients. 2015;7(4):2866-78. https://doi.org/10.3390/nu7042866

26. National Health and Medical Research Council. Australian Dietary Guidelines. Canberra: National Health and Medical Research Council; 2013.

27. Ministry of Health (New Zealand). Food and nutrition guidelines for healthy older people: A background paper. Wellington: Ministry of Health; 2013.

28. Vorster HH, Badham JB, Venter CS. An introduction to the revised food-based dietary guidelines for South Africa. S Afr J Clin Nutr. 2013;26(3Suppl.):S1-S164. 2013;26(3):1-16.

29. Bantle JP, Wylie-Rosett J, Albright AL, Apovian CM, ClarkNG, FranzMJ, etal. Nutrition recommendations and interventions for diabetes: A position statement of the American Diabetes Association. Diabetes Care. 2008;31(Suppl.1):S61-78. https://doi.org/10. 2337/dc08-S061

30. European Food Safety Authority. Scientific opinion on dietary reference values for carbohydrates and dietary fibre. EFSA J. 2010;8(3):1462.

31. Ministério da Saúde (Brasil). Guia alimentar para a população brasileira. $2^{a}$ ed. Brasília: Ministério da Saúde; 2014.

32. Ministério da Saúde (Brasil) Guia alimentar para a população brasileira: promovendo a alimentação saudável. Brasília: Ministério da Saúde; 2006.

33. Popkin BM, Hawkes C. Sweetening of the global diet, particularly beverages: Patterns, trends, and policy responses. Lancet Diabetes Endocrinol. 2015;4(2):174-86. https://doi.org/10.1016/\$2213-8 587(15)00419-2

34. Scapin T. Notificação dos açúcares de adição em rótulos de alimentos industrializados comer- 
cializados no Brasil [dissertação]. Florianópolis: Universidade Federal de Santa Catarina; 2016.

35. Smith C, Marks AD, Lieberman M. Basic medical biochemistry: A clinical approach. Philadelphia: Lippincott Williams \& Williams; 2005.

36. Barreiros RC, Bossolan G, Trindade CEP. Frutose em humanos: efeitos metabólicos, utilização clínica e erros inatos associados. Rev Nutr. 2005;18:377-89. https://doi.org/10.1590/S141552732005000300010

37. Stanhope KL, Havel PJ. Fructose consumption: Considerations for future research on its effects on adipose distribution, lipid metabolism, and insulin sensitivity in humans. J Nutr. 2009;139(6):1236s-41s. https://doi.org/10.3945/ jn.109.106641

38. Malik VS, Schulze MB, Hu FB. Intake of sugarsweetened beverages and weight gain: A systematic review. Am J Clin Nutr. 2006;84(2):274-88.

39. Stanhope KL, Havel PJ. Fructose consumption: Potential mechanisms for its effects to increase visceral adiposity and induce dyslipidemia and insulin resistance. Curr Opin Lipidol. 2008;19(1):16-24. https://doi.org/10.1097/MOL.0b0 $13 \mathrm{e} 3282 \mathrm{f} 2 \mathrm{~b} 24 \mathrm{a}$

40. DiNicolantonio JJ, O'Keefe JH, Lucan SC. Added fructose: A principal driver of type 2 diabetes Mellitus and its consequences. Mayo Clin Proc. 2015;90(3):372-81. https://doi.org/10.1016/j. mayocp. 2014.12.019

41. Greenwood DC, Threapleton DE, Evans CE, Cleghorn CL, Nykjaer C, Woodhead C, et al. Association between sugar-sweetened and artificially sweetened soft drinks and type 2 diabetes: Systematic review and dose-response meta-analysis of prospective studies. $\mathrm{Br} J$ Nutr. 2014;112(5):725-34. https://doi.org/10.1017/s0007 114514001329

42. Xi B, Li S, Liu Z, Tian H, Yin X, Huai P, et al. Intake of fruit juice and incidence of type 2 diabetes: A systematic review and meta-analysis. PLoS ONE. 2014;9(3):93471. https://doi.org/10.1371/ journal.pone.0093471

43. Aune D, Chan DS, Vieira AR, Navarro Rosenblatt DA, Vieira R, Greenwood DC, et al. Dietary fructose, carbohydrates, glycemic indices and pancreatic cancer risk: A systematic review and meta-analysis of cohort studies. ESMO. 2012;23(10):2536-46. https://doi.org/10.1093/annond mds076

44. Kaaks R, Lukanova A. Energy balance and cancer: The role of insulin and insulin-like growth factor-I. Proc Nutr Soc. 2001;60(1):91-106.

45. Michaud DS, Fuchs CS, Liu S, Willett WC, Colditz GA, Giovannucci E. Dietary glycemic load, carbohydrate, sugar, and colorectal cancer risk in men and women. Cancer Epidemiol Biomarkers Prev. 2005;14(1):138.

46. Galeone C, Pelucchi C, La Vecchia C. Added sugar, glycemic index and load in colon cancer risk. Curr Opin Clin Nutr Metab Care. 2012;15(4):368-73. https:// doi.org/10.1097/MCO.0b013e $3283539 f 81$

47. Reiner Z, Catapano AL, De Backer G, Graham I, Taskinen MR, Wiklund $\mathrm{O}$, et al. Guidelines for the management of dyslipidaemias: The task force for the management of dyslipidaemias of the European Society of Cardiology (ESC) and the European Atherosclerosis Society (EAS). Atherosclerosis. 2011;217(1):3-46.

48. Welsh JA, Sharma A, Abramson JL, Vaccarino V, Gillespie C, Vos MB. Caloric sweetener consumption and dyslipidemia among us adults. JAMA. 2010;303(15):1490-7. https://doi.org/10.1001/ jama.2010.449

49. Te Morenga LA, Howatson AJ, Jones RM, Mann J. Dietary sugars and cardiometabolic risk: Systematic review and meta-analyses of randomized controlled trials of the effects on blood pressure and lipids. Am J Clin Nutr. 2014;100(1):65-79. https://doi.org/10.3945/ajcn.113.081521

50. Huang C, Huang J, Tian Y, Yang X, Gu D. Sugar sweetened beverages consumption and risk of coronary heart disease: A meta-analysis of prospective studies. Atherosclerosis. 2014;234(1):11-6. https:// doi.org/10.1016/j.atherosclerosis. 2014.01.037

51. Wang DD, Sievenpiper JL, de Souza RJ, Cozma Al, Chiavaroli L, Ha V, et al. Effect of fructose on postprandial triglycerides: A systematic review and meta-analysis of controlled feeding trials. Atherosclerosis. 2014;232(1):125-33.

52. Zhang YH, An T, Zhang RC, Zhou Q, Huang Y, Zhang J. Very high fructose intake increases serum LDL-cholesterol and total cholesterol: A meta-analysis of controlled feeding trials. J Nutr. 2013;143:1391-8.

53. Choi HK, Curhan G. Soft drinks, fructose consumption, and the risk of gout in men: Prospective cohort study. BMJ. 2008;336(7639):309-12. https://doi.org/10.1136/bmj.3944 9.819271.BE

54. Johnson RJ, Segal MS, Sautin Y, Nakagawa T, Feig DI, Kang D-H, et al. Potential role of sugar (fructose) in the epidemic of hypertension, obesity and the metabolic syndrome, diabetes, kidney disease, and cardiovascular disease. Am J Clin Nutr. 2007;86(4):899-906.

55. Madero M, Perez-Pozo SE, Jalal D, Johnson RJ, Sanchez-Lozada LG. Dietary fructose and hypertension. Curr Hypertens Rep. 2011;13(1):29-35. https://doi.org/10.1007/s11906-010-0163-x 
56. Johnson RJ, Sanchez-Lozada Lg, Nakagawa T. The effect of fructose on renal biology and disease. J Am Soc Nephrol. 2010;21:2036-9.

57. Ha V, SievenpiperJl, de Souza RJ, Chiavaroli L, Wang DD, Cozma Al, et al. Effect of fructose on blood pressure: A systematic review and metaanalysis of controlled feeding trials. Hypertension. 2012;59(4):787-95.

58. Malik AH, Akram Y, Shetty S, Malik SS, Yanchou Njike V. Impact of sugar-sweetened beverages on blood pressure. Am J Cardiol. 2014;113(9):1574-80. https://doi.org/10.1016/j. amjcard.2014.01.437

59. Goldfein KR, Slavin JL. Why sugar is added to food: Food science 101. Compr Rev Food Sci Food Saf. 2015;14(5):644-56. https://doi. org/10.1111/1541-4337.12151

60. Fitch C, Keim KS. Position of the Academy of Nutrition and Dietetics: Use of Nutritive and Nonnutritive Sweeteners. J Acad Nutr Diet. 2012;112(5):739-58. https://doi.org/10.1016/j. jand.2012.03.009

61. Miller PE, Perez V. Low-calorie sweeteners and body weight and composition: A meta-analysis of randomized controlled trials and prospective cohort studies. Am J Clin Nutr. 2014;100(3):76577. https://doi.org/10.3945/ajcn.113.082826

62. Rogers PJ, Hogenkamp PS, de Graaf C, Higgs S, Lluch A, Ness $A R$, et al. Does low-energy sweetener consumption affect energy intake and body weight? A systematic review, including meta-analyses, of the evidence from human and animal studies. Int J Obes (Lond). 2016;40(3):381-94. https://doi.org/10.1038/ijo.2015.177

63. Swithers SE. Artificial sweeteners produce the counterintuitive effect of inducing metabolic derangements. Trends Endocrinol Metab. 2013;24(9):431-41. https://doi.org/10.1016/.tem.2013. 05.005

64. Pepino MY. Metabolic effects of non-nutritive sweeteners. Physiol Behav. 2015;152:450-5. https:// doi.org/10.1016/j.physbeh.2015.06.024

65. Mattes RD, Popkin BM. Nonnutritive sweetener consumption in humans: Effects on appetite and food intake and their putative mechanisms. Am J Clin Nutr. 2009;89(1):1-14. https://doi.org/10. 3945/ajcn.2008.26792

66. Shankar P, Ahuja S, Sriram K. Non-nutritive sweeteners: Review and update. Nutrition. 2013;29(11-12):1293-9. https://doi.org/10.10 16/j.nut.2013.03.024

67. Gardner C. Non-nutritive sweeteners: Evidence for benefit vs. risk. Curr Opin Lipidol. 2014;25(1):80-4. https://doi.org/10.1097/mol.0000000000000034

Received: August 18, 2016

Final version: December 6, 2016 Approved: February 20, 2017 
